\title{
HUBUNGAN ANTARA PENGETAHUAN IBU DENGAN POLA ASUH MAKAN TERHADAP STATUS GIZI ANAK DI KOTA JAMBI
}

\section{Relationship between Mother Knowledge with Patterns Eating on The Nutrition Status of Children in Jambi City}

\author{
M. Dody Izhar ${ }^{1}$ \\ ${ }^{1}$ Program Studi Kesehatan Masyarakat \\ Fakultas Kesehatan Masyarakat Universitas Jambi
}

\begin{abstract}
ABSTRAK
Asupan gizi memegang peranan penting dalam meningkatkan kualitas sumber daya manusia. Pengetahuan tentang pola asuh makan sangat berkontribusi terhadap status gizi anak, dalam mengoptimalkan pertumbuhan dan perkembangan anak. Penelitian ini merupakan penelitian observasional dengan rancangan cross sectional. Responden dalam penelitian ini adalah ibu yang memiliki balita usia 12-24 bulan sebanyak 78 ibu balita yang diambil secara one stages cluster sampling. Keseluruhan analisis menggunakan software analisis statistik dengan tingkat kemaknaan uji $\mathrm{p}<0,05$. Hasil penelitian diketahui bahwa pengetahuan kurang baik sebanyak 26 ibu (33,3\%), pola asuh kurang baik sebanyak $47 \mathrm{ibu}(60,3 \%)$ dan status gizi kurang sebanyak 12 balita $(15,4 \%)$. Ada hubungan secara signifikan pengetahuan ibu dengan pola asuh makan $(p=0,001)$, dan ada hubungan secara signifikan pola asuh makan dengan status gizi anak $(p=0,022)$, berdasarkan analisis stratifikasi tidak ada perbedaan antara pengetahuan yang baik $(p=1,000)$ dan kurang baik $(p=0,208)$ dengan pola asuh makan terhadap status gizi. Penelitian ini menyimpulkan bahwa ada hubungan yang signifikan antara pengetahuan ibu dan pola asuh makan terhadap status gizi anak di Kota Jambi.
\end{abstract}

Kata Kunci : Pengetahuan, pola asuh, status gizi

\begin{abstract}
Nutrition intake plays an important role in improving the quality of human resources. Knowledge of eating patterns greatly contributes to the nutritional status of children, in optimizing the growth and development of children. This research is an observational research with cross sectional design. Respondents in this study are mothers who have children aged 12-24 months as many as 78 mothers under five taken one stages cluster sampling. The overall analysis used statistical analysis software with significance level of test $\mathrm{p}<0,05$. The result of the research shows that knowledge is not good as much as 26 mothers $(33,3 \%)$, bad mother pattern as much as 47 mothers $(60,3 \%)$ and nutritional status less $12(15,4 \%)$. There was a significant correlation of mother's knowledge with eating pattern $(\mathrm{p}=0,001)$, and there was a significant correlation between feeding pattern with child nutritional status $(\mathrm{p}=0,022)$, based on stratification analysis there was no difference between good knowledge $(\mathrm{p}=1,000)$ and poor $(\mathrm{p}=0,208)$ with eating pattern to nutritional status. This study concludes that there is a significant relationship between maternal knowledge and the pattern of feeding on the nutritional status of children in Jambi City.
\end{abstract}

Keywords: Knowledge, parenting, nutritional status

Korespondensi : M. Doddy Izhar

Email : mdodyizhar@unja.co.id 


\section{PENDAHULUAN}

Status gizi memegang peranan penting dalam meningatkan kualitas sumber daya manusia. Kekurangan gizi dapat menghambat pertumbuhan fisik, perkembangan kecerdasan, penurunan produktivitas, menurunnya daya tahan tubuh, meningkatkan angka kesakitan dan kematian (Almatsier, 2009).

Kasus gizi kurang menurut WHO masih menjadi perhatian dunia, pada tahun 2013, 17\% atau 98 juta anak di bawah lima tahun di negara berkembang mengalami kurang gizi (berat badan rendah menurut umur berdasarkan standar WHO). Prevalensi tertinggi berada di wilayah Asia Selatan sebesar 30\%, kemudian di ikuti oleh Afrika Barat 21\%, Osceania dan Afrika Timur 19\%, Asia Tenggara dan Afrika Tengah 16\%, dan Afrika Selatan $12 \%$.

Menurut UNICEF (1998), faktorfaktor yang mempengaruhi status gizi anak balita dan penyebab kurang gizi pada anak balita di masyarakat yaitu : penyebab langsung dan tidak langsung. Asupan makanan dan penyakit dapat secara langsung menyebabkan gizi kurang. Sedangkan penyebab tidak langsung ada 3 yaitu, ketahanan pangan, pola asuh anak, serta pelayanan kesehatan dan lingkungan yang tidak memadai. Hal ini disebabkan karena kemiskinan, pendapatan, kurang pendidikan,

pengetahuan

dan keterampilan.

Prevalensi nasional masalah gizi buruk dan gizi kurang (BB/U) pada anak balita masih tinggi yaitu 19,6\%. Jika di bandingkan dengan angka Prevalensi Nasional tahun $2007(18,4 \%)$ dan tahun $2010(17,9 \%)$ terlihat meningkat. Dari 33 Provinsi Jambi memiliki prevalensi gizi buruk dan gizi kurang di atas angka prevalensi nasional yaitu $19,7 \%$ pada tahun 2013 (riskesdas 2013).

Berdasarkan hasil Penilaian Status Gizi (PSG) Prevalensi Status Gizi buruk dan kurang $(\mathrm{BB} / \mathrm{U})$ di Provinsi Jambi tahun 2016 sebesar 15,6\%. Sedangkan menurut hasil Penilaian Status Gizi (PSG) di Kota Jambi Prevalensi Status Gizi buruk dan kurang $(\mathrm{BB} / \mathrm{U})$ di Kota Jambi tahun 2016 sebesar 18,4\%. (Dinkes Provinsi,2016)

Kota Jambi pada tahun 2015 menunjukkan bahwa prevalensi status gizi balita yang mengalami gizi kurang 286 $(0,9 \%)$. Apabila dibandingkan dengan tahun 2016 yang menunjukkan prevalensi status gizi balita yang mengalami gizi kurang sebesar 290 (1,3\%) (Dinkes Kota Jambi, 2016)

Masa anak di bawah lima tahun merupakan periode penting dalam tumbuh kembang anak karena pertumbuhan dasar yang berlangsung pada masa balita akan 
mempengaruhi dan menentukan perkembangan anak selanjutnya. Seperti diketahui bahwa tiga tahun (baduta) pertama merupakan periode keemasan (golden period), yaitu terjadi optimalisasi proses tumbuh kembang. Dalam pertumbuhan dan perkembangan anak memerlukan zat-zat gizi agar proses pertumbuhan dan perkembangan berjalan dengan baik (Gunawan, dkk, 2011).

Pola pengasuhan anak dalam pemberian makan sehari-hari ditentukan oleh tingkat pendidikan ibu dan pengetahuan ibu tentang gizi balita. Sebagian besar kejadian gizi kurang dapat dihindari apabila ibu sebagai orang yang paling dekat dengan anak mempunyai pengetahuan yang cukup tentang gizi. Pengetahuan yang harus diketahui oleh seorang ibu adalah tentang kebutuhan gizi, cara pemberian makan, jadwal pemberian makan pada balita, sehingga akan menjamin anak dapat tumbuh dan berkembang dengan optimal (Supariasa, 2015).

Pola pengasuhan sangat berkontribusi terhadap status gizi anak. Anak yang memperoleh pola asuh makan yang kurang akan cenderung mengalami sulit makan hal ini akan mempengaruhi tingkat konsumsi anak tersebut, baik energi maupun protein. Salah satu pola pengasuhan yang berhubungan dengan status gizi anak adalah pola asuh makan (Karyadi,1985 dalam Yulia, dkk., 2008).

Pola asuh makan adalah praktikpraktik pengasuhan yang di terapkan ibu kepada anak yang berkaitan dengan cara dan situasi makan. Jumlah dan kualitas makanan yang dibutuhkan untuk konsumsi anak penting sekali dipikirkan, direncanakan dan dilaksanakan oleh ibu atau pengasuhnya yang berkaitan dengan kegiatan pemberian makan yang akhirnya akan memberikan sumbangan status gizi (Istiany dan Rusilanti, 2013).

Berdasarkan data dan pernyataan diatas maka penulis tertarik untuk melakukan penelitian tentang "Hubungan antara Pengetahuan Ibu dengan Pola Asuh Makan terhadap Status Gizi Anak Di Kota Jambi Tahun 2017”.

\section{BAHAN DAN METODE}

Jenis penelitian yang digunakan adalah observasional dengan rancangan cross sectional. ${ }^{9}$ Penelitian ini dilakukan di wilayah kerja Puskesmas Talang Bakung Kota Jambi pada bulan 21-28 Agustus 2017. Populasi dalam penelitian ini adalah ibu yang memiliki anak usia 12-24 bulan berjumlah 399 anak. Besar sampel minimal sebanyak 78 anak. Pengambilan sampel menggunakan metode one stages cluster sampling. ${ }^{10}$ 
Data dikumpulkan melalui dengan menggunakan perangkat komputer wawancara dan penimbangan, timbangan dan dianalisis secara deskriptif dan digital, tabel antropometri WHO 2005 dari analitik.

Depkes RI (2010), data pengetahuan dan pola asuh makan dilakukan dengan wawancara langsung pada responden dengan kuesioner. Penilaian status gizi menggunakan timbangan digital dan tabel antropometri WHO 2005. Data diolah

\section{HASIL PENELITIAN}

Berdasarkan dari hasil penelitian didapatkan karakteristik balita berdasarkan jenis kelamin dan umur (bulan) dapat disampaikan sebagai berikut :

Tabel 1. Distribusi karakteristik balita berdasarkan jenis kelamin dan umur di wilayah kerja Puskesmas Talang Bakung Kota Jambi Tahun 2017

$(\mathrm{N}$ Total $=78$ subjek $)$

\begin{tabular}{lcc}
\hline \multicolumn{1}{c}{ Karakteristik Balita } & Frekuensi & \% \\
\hline Jenis Kelamin & & \\
$\quad$ Laki-laki & 38 & 48,72 \\
$\quad$ Perempuan & 40 & 51,28 \\
Umur (Mean \pm SD) & $16,73 \pm 3,42$ & \\
Berat Badan (Mean \pm SD) & $9,30 \pm 1,27$ & \\
\hline
\end{tabular}

Dilihat dari Tabel 1 diatas, dari 78 responden balita, lebih dari sebagiannya yang menjadi responden berjenis kelamin perempuan yaitu sebesar $51,28 \%$, dengan rata-rata dan simpangan baku umur balita (bulan) sebesar 16,73 $\pm 3,42$ serta rata-rata dan simpangan baku berat badan $(\mathrm{Kg})$ sebesar 9,30 $\pm 1,27$.

Berdasarkan karakteristik ibu balita berdasarkan umur, pendidikan, pekerjaan dan pendapatan keluarga, diketahui bahwa 
Tabel 2. Distribusi Karakteristik Ibu Berdasarkan Umur, Pendidikan, Pekerjaan dan Pendapatan di Wilayah Kerja Puskesmas Talang Bakung Kota Jambi Tahun 2017

$(\mathrm{N}$ Total $=78$ subjek $)$

\begin{tabular}{lcc}
\hline \multicolumn{1}{c}{ Karakteristik Ibu } & Frekuensi & \% \\
\hline Umur (Mean \pm SD) & $31,67 \pm 6,61$ & \\
\hline Pendidikan & & \\
SD & 1 & 1,28 \\
SMP & 14 & 17,95 \\
SMA & 50 & 64,10 \\
PT & 13 & 16,67 \\
Pekerjaan & & \\
IRT & 57 & 73,08 \\
Pegawai swasta & 14 & 17,95 \\
PNS & 5 & 6,41 \\
$\quad$ Wiraswasta & 2 & 2,56 \\
Pendapatan & & \\
$\quad$ < Rp. 2.000.000,- & 24 & 30,77 \\
$\quad$ Rp. 2.000.000,- & 54 & 69,23 \\
\hline
\end{tabular}

Dilihat dari tabel 2 diatas, dari 78 responden ibu balita, diketahui rata-rata unmur ibu sebesar 31,67 tahun, pendidikan terbanyak adalah SMA $(64,10 \%)$, pekerjaan sebagian besar adalah ibu rumah tangga $(73,08 \%)$ dan pendapatan sebagian besar $(69,23 \%)$ adalah $\geq$ Rp. 2.000.000,-.
Distribusi data terhadap variabelvariabel penelitian yang terdiri dari pengetahuan, pola asuh makan dan status gizi balita di wilayah kerja Puskesmas Talang Bakung Jambi Tahun 2017 dapat disampaikan pada Tabel 3 berikut ini :

Tabel 3. Distribusi pengetahuan ibu, pola asuh makan dan status gizi anak di Wilayah Kerja Puskesmas Talang Bakung Kota Jambi Tahun 2017

$(\mathrm{N}$ Total $=78$ subjek $)$

\begin{tabular}{lcc}
\hline Variabel & Frekuensi & \% \\
\hline Pengetahuan Ibu & & \\
Kurang baik & 26 & 33,33 \\
$\quad$ Baik & 52 & 66,67 \\
Pola Asuh Makan & & \\
$\quad$ Kurang baik & 47 & 60,26 \\
$\quad$ Baik & 31 & 39,74 \\
Status Gizi & & \\
$\quad$ Kurang & 12 & 15,38 \\
Baik & 66 & 84,62 \\
\hline
\end{tabular}


Dilihat dari tabel 3 diatas, kemudian menghubungkan lagi variabel pengetahuan ibu tentang gizi diketahui pola asuh makan dengan status gizi balita kurang baik sebesar $33,33 \%$, berdasarkan serta analisis stratifikasi pengetahuan ibu berat badan per umur didapatkan balita dengan status gizi kurang sebesar 15,38\% dan penerapan terhadap pola asuh makan pada anak kurang baik sebesar 60,26\% .

Data yang telah terkumpul selanjutnya dilakukan analisis bivariat, terhadap status gizi berdasarkan pola asuh makan

Pengujian hubungan antara pengetahuan ibu tentang gizi dengan pola asuh makan, dapat disampaikan sebagai berikut :

dilakukan dalam dua tahapan yaitu menghubungkan antara variabel pengetahuan dengan pola asuh makan dan

Tabel 4. Hubungan pengetahuan ibu dengan pola asuh makan di Wilayah Kerja Puskesmas Talang Bakung Kota Jambi Tahun 2017

\begin{tabular}{|c|c|c|c|c|c|c|c|}
\hline \multirow{3}{*}{ Pengetahuan } & \multicolumn{4}{|c|}{ Pola Asuh Makan } & \multirow{2}{*}{\multicolumn{2}{|c|}{ Jumlah }} & \multirow{3}{*}{ p-value } \\
\hline & \multicolumn{2}{|c|}{ Kurang Baik } & \multicolumn{2}{|c|}{ Baik } & & & \\
\hline & $\mathrm{n}$ & $\%$ & $\mathrm{n}$ & $\%$ & $\mathrm{n}$ & $\%$ & \\
\hline Kurang Baik & 23 & 88,46 & 3 & 11,54 & 26 & 100 & \\
\hline Baik & 24 & 46,15 & 28 & 53,85 & 52 & 100 & 0.001 \\
\hline Jumlah & 47 & 60,26 & 31 & 39,74 & 78 & 100 & \\
\hline
\end{tabular}

Berdasarkan tabel 4, dapat disampaikan bahwa ibu yang memiliki pengetahuan kurang baik, $88,46 \%$ menerapkan pola asuh makan yang kurang baik. Sedangkan ibu yang memiliki pengetahuan baik, hanya $46,15 \%$ menerapkan pola asuh makan yang kurang baik. Hasil analisis didapatkan nilai $p$ value sebesar 0,001, dengan demikian diketahui bahwa ada hubungan yang signifikan antara pengetahuan ibu balita tentang gizi dengan pola asuh makan yang diberikan pada balita.

Selanjutnya dilakukan analisis pola asuh makan dengan status gizi pada anak. Adapun hasil analisis dapat disampaikan sebagai berikut : 
Tabel 5. Hubungan antara pola asuh makan dengan status gizi anak di Wilayah Kerja Puskesmas Talang Bakung Kota Jambi Tahun 2017

\begin{tabular}{|c|c|c|c|c|c|c|c|}
\hline \multirow{3}{*}{$\begin{array}{c}\text { Pola Asuh } \\
\text { Makan }\end{array}$} & \multicolumn{4}{|c|}{ Status Gizi } & \multirow{2}{*}{\multicolumn{2}{|c|}{ Jumlah }} & \multirow{3}{*}{$p$-value } \\
\hline & \multicolumn{2}{|c|}{ Kurang } & \multicolumn{2}{|c|}{ Normal } & & & \\
\hline & $\mathrm{n}$ & $\%$ & $\mathrm{n}$ & $\%$ & $\mathrm{n}$ & $\%$ & \\
\hline Kurang Baik & 11 & 23,40 & 36 & 76,60 & 47 & 100 & \\
\hline Baik & 1 & 3,26 & 30 & 96,74 & 31 & 100 & 0.022 \\
\hline Jumlah & 12 & 15,38 & 66 & 84,62 & 78 & 100 & \\
\hline
\end{tabular}

Berdasarkan tabel 5, dapat disampaikan bahwa pola asuh makan yang kurang baik, 23,40\% diketahui sebesar $23,40 \%$ mengalami status gizi dengan kategori kurang. Sedangkan pola asuh makan baik diketahui hanya sebesar $3,26 \%$ mengalami status gizi dengan kategori kurang. Didapatkan nilai p-value sebesar 0,022, dengan demikian diketahui bahwa terdapat hubungan yang signifikan antara pola asuh makan dengan status gizi balita di wilayah kerja Puskesmas Talang Bakung Kota Jambi tahun 2017.

Berdasarkan konsep teori bahwa pengetahuan ibu tentang gizi dengan status gizi pada anak dipengaruhi oleh pola asuh makan maka, selanjutnya dilakukan analisis stratifikasi. Adapun hasil analisis dapat disampaikan sebagai berikut :

Tabel 6. Analisis stratifikasi hubungan antara pengetahuan dengan pola asuh makan terhadap status gizi anak di Wilayah Kerja Puskesmas Talang Bakung Kota Jambi Tahun 2017

\begin{tabular}{|c|c|c|c|c|c|c|c|c|c|}
\hline \multicolumn{3}{|c|}{ Variabel } & \multicolumn{4}{|c|}{ Status Gizi } & \multirow{2}{*}{\multicolumn{2}{|c|}{ Jumlah }} & \multirow{3}{*}{$p$-value } \\
\hline & & & \multicolumn{2}{|c|}{ Kurang } & \multicolumn{2}{|c|}{ Normal } & & & \\
\hline & & & $\mathrm{n}$ & $\%$ & $\mathrm{n}$ & $\%$ & $\mathrm{n}$ & $\%$ & \\
\hline \multicolumn{10}{|l|}{ Pengetahuan } \\
\hline \multirow[t]{3}{*}{ Kurang Baik } & $\begin{array}{l}\text { Pola } \\
\text { Asuh }\end{array}$ & $\begin{array}{l}\text { Kurang } \\
\text { Baik }\end{array}$ & 9 & 39,1 & 14 & 60,9 & 23 & 100 & \multirow{3}{*}{1.000} \\
\hline & Makan & Baik & 1 & 33,3 & 2 & 66,7 & 3 & 100 & \\
\hline & \multicolumn{2}{|c|}{ Jumlah } & 10 & 38,5 & 16 & 61,55 & 26 & 100 & \\
\hline \multirow[t]{3}{*}{ Baik } & $\begin{array}{l}\text { Pola } \\
\text { Asuh }\end{array}$ & $\begin{array}{l}\text { Kurang } \\
\text { Baik }\end{array}$ & 2 & 8,3 & 22 & 91,7 & 24 & 100 & \multirow{3}{*}{0.208} \\
\hline & Makan & Baik & 0 & 0 & 28 & 100 & 28 & 100 & \\
\hline & \multicolumn{2}{|c|}{ Jumlah } & 2 & 3,9 & 50 & 96,1 & 52 & 100 & \\
\hline
\end{tabular}


Tabel 12

Hubungan Antara Pengetahuan dengan Pola Asuh Terhadap Status Gizi Balita di Wilayah Kerja Puskesmas Talang Bakung Kota Jambi Tahun 2017

\begin{tabular}{|c|c|c|c|c|c|c|c|c|c|}
\hline \multirow{3}{*}{\multicolumn{3}{|c|}{ Pengetahuan }} & \multicolumn{4}{|c|}{ Status Gizi } & \multirow{2}{*}{\multicolumn{2}{|c|}{ Jumlah }} & \multirow{3}{*}{$\begin{array}{c}p- \\
\text { value }\end{array}$} \\
\hline & & & \multicolumn{2}{|c|}{ Kurang } & \multicolumn{2}{|c|}{ Baik } & & & \\
\hline & & & $\mathrm{n}$ & $\%$ & $\mathrm{n}$ & $\%$ & $\mathrm{n}$ & $\%$ & \\
\hline \multirow{3}{*}{$\begin{array}{c}\text { Kurang } \\
\text { Baik }\end{array}$} & Pola & $\begin{array}{c}\text { Kurang } \\
\text { Baik }\end{array}$ & 9 & $\begin{array}{c}39, \\
1\end{array}$ & 14 & 60,9 & 23 & $\begin{array}{c}10 \\
0\end{array}$ & \multirow{3}{*}{1.000} \\
\hline & $\begin{array}{l}\text { Asuh } \\
\text { Makan }\end{array}$ & Baik & 1 & $\begin{array}{c}33, \\
3\end{array}$ & 2 & 66,7 & 3 & $\begin{array}{c}10 \\
0\end{array}$ & \\
\hline & \multicolumn{2}{|c|}{ Jumlah } & 10 & $\begin{array}{c}38, \\
5\end{array}$ & 16 & $\begin{array}{c}61,5 \\
5\end{array}$ & 26 & $\begin{array}{c}10 \\
0\end{array}$ & \\
\hline \multirow{3}{*}{ Baik } & Pola & $\begin{array}{c}\text { Kurang } \\
\text { Baik }\end{array}$ & 2 & 8,3 & 22 & 91,7 & 24 & $\begin{array}{c}10 \\
0\end{array}$ & \multirow{3}{*}{0.208} \\
\hline & $\begin{array}{l}\text { Asun } \\
\text { Makan }\end{array}$ & Baik & 0 & 0 & 28 & 100 & 28 & $\begin{array}{c}10 \\
0\end{array}$ & \\
\hline & \multicolumn{2}{|c|}{ Jumlah } & 2 & 3,9 & 50 & 96,1 & 52 & $\begin{array}{c}10 \\
0\end{array}$ & \\
\hline
\end{tabular}

Hasil uji stratafikasi juga menunjukkan, pengetahuan yang baik dan hubungannya dengan pola asuh makan serta status gizi didapatkan nilai $p$-value 0.208 yang artinya nilai tersebut lebih besar dari nilai $\alpha$ (0.005), maka tidak ada hubungan yang signifikan antara pengetahuan yang baik dengan pola asuh makan dan status gizi balita.

Dari tabel 12 dapat dilihat bahwa dari 23 ibu yang berpengetahuan kurang baik tentang gizi memiliki pola asuh makan yang kurang baik, yang membuat jumlah anak berstatus gizi kurang sebanyak 9 $(39,1 \%)$ dan anak dengan status gizi baik sebanyak 14 (60,9\%), sedangkan dari $3 \mathrm{ibu}$ yang pengetahuan gizinya kurang baik namun menerapkan pola asuh makan yang baik, memiliki anak dengan status gizi kurang hanya 1 orang $(33,3 \%)$ dan 2 lainnya memiliki anak dengan status gizi baik $(66,7 \%)$. Dari 24 orang ibu yang memiliki pengetahuan tentang gizi baik namun pola asuh makan yang diterapkan pada anak kurang baik memiliki anak dengan status gizi kurang sebanyak 2 $(8,3 \%)$ dan anak dengan status gizi baik sebanyak $22(91,7 \%)$. Dari 28 orang ibu yang memiliki pengetahuan tentang gizi baik serta penerapan pola asuh makannya baik kepada balita seluruhnya memiliki anak dengan status gizi baik atau sebanyak 28 (100\%). 


\section{PEMBAHASAN}

\section{Hubungan Pengetahuan Ibu tentang} Gizi dengan Pola Asuh Makan di Wilayah Kerja Puskesmas Talang Bakung Kota Jambi Tahun 2017.

Berdasarkan hasil penelitian terdapat hubungan yang signifikan antara pengetahuan ibu tentang gizi dengan pola asuh makan di wilayah kerja Puskesmas Talang Bakung Kota Jambi tahun 2017 dengan nilai $p$-value 0.001 . Kebanyak ibu yang memiliki pengetahuan kurang baik menerapkan pola asuh makan yang kurang baik pula pada balitanya.

Kurangnya pengetahuan tentang gizi atau kemampuan untuk menerapkan informasi gizi dalam kehidupan sehari-hari merupakan sebab penting dari gangguan gizi (Suhardjo, 1986 dalam Irianto, 2014). Ketidak tahuan tentang cara pemberian makanan bayi dan anak balita adalah kebiasaan yang merugikan kesehatan, secara langsung dan tidak langsung menjadi penyebab utama terjadinya masalah kurang gizi pada anak, khususnya pada anak usia dibawah 2 tahun (departemen Kesehatan dan Kesejahteraan Sosial RI, 2000).

Pengetahuan gizi orang tua dan pengasuh anak ternyata sangat berpengaruh terhadap pilihan makanan anak. Tingkat pengetahuan gizi yang dipraktikan pada pencernaan makanan keluarga tempaknya berhubungan dengan sikap positif ibu terhadap diri sendiri, kemampuan ibu dalam memecahkan masalah, dan mengorganisasikan keluarga (Istiany dan Rusilanti, 2013).

Tetapi pada penelitian ini, terdapat juga ibu yang memiliki pengetahuan yang baik tentang gizi namun pola asuh makan yang diterapkannya kurang baik. hal ini terjadi karena kurangnya waktu ibu dalam memperhatikan anaknya karena sebagian ibu yang memiliki pola asuh yang kurang baik bekerja diluar rumah, dari 12 anak yang dengan status gizi kurang, 4 diantaranya memiliki ibu yang bekerja. Menurut Notoatmodjo (2011) pekerjaan adalah kegiatan yang menyita waktu. Pola asuh yang kurang baik juga dipengaruhi oleh fakor ekonomi dalam sebuah keluarga, beberapa responden yang memiliki pengetahuan yang baik namun kurang baik dalam penerapan pola asuh makan pada balita berpenghasilan kurang dari standar kebutuhan, sehingga ketersediaan pangan untuk kebutuhan sehari-hari juga kurang memadai. Menurut Irianti (2014), pendapatan keluarga yang memadai akan menunjang tumbuuh kembang anak karena orang tua dapat menyediakan semua kebutuhan anak baik yang primer maupun sekunder.

Ibu yang memiliki pengetahuan yang kurang baik namun penerapan pola asuh makan pada balitanya baik, memiliki kesadaran akan pentingnya makanan untuk anaknya, dan juga sebagian ibu didukung oleh anggota keluarga yang lain untuk memberikan makanan pada anak sesuai dengan kebutuhannya.

Penelitian ini sejalan dengan penelitian yang dilakukan oleh Kusumaputra RP (2015) yang meneliti tentang hubungan pola asuh dan pengetahuan ibu dengan status gizi dan kesehatan balita di PAUD At Taqwa dan PAUD Eka Mandiri di Kecamatan Cinangneng dengan nilai $p$ value 0.025 .

Untuk meningkatkan pengetahuan ibu tentang pola asuh makan yang baik untuk balita perlu dilakukannya edukasi seperti penyuluhan ataupun pelatihan tentang gizi 
yang menjelaskan fungsi zat gizi untuk tumbuh kembang balita, hingga sumber zat-zat gizi yang memungkinkan untuk setiap keluarga mendapatkannya dengan harga yang terjangkau, sehingga keluarga dengan pendapatan rendah dapat memenuhi kebutuhan gizinya dengan bahan makanan yang terjangkau.

\section{Hubungan Pola Asuh Makan dengan Status Gizi Balita di Wilayah Kerja Puskesmas Talang Bakung Kota Jambi Tahun 2017.}

Berdasarkan hasil penelitian didapatkan bahwa adanya hubungan yang signifikan antara pola asuh makan dengan status gizi balita di wilayah kerja Puskesmas Talang Bakung Kota Jambi tahun 2017 dengan nilai $p$-value 0.022 . Pola asuh makan yang diterapkan ibu pada balita masih banyak yang kurang baik, sehingga balita memiliki status gizi yang kurang pula. Pemberian makanan yang memenuhi zat-zat gizi lengkap seperti karbohidrat, protein, lemak, vitamin dan mineral kadang-kadang diberikan oleh ibu kepada balitanya dan bahkan terdapat beberapa ibu yang tidak pernah memberikan anaknya makanan yang bergizi lengkap yang hanya memberikan dua zat gizi saja seperti karbohidrat dan protein. Pemberian makanan selingan atau snack kepada balita juga jarang dilakukan oleh ibu-ibu dan bahkan tidak pernah, ibu-ibu lebih suka memberikan jajanan diwarung kepada balitanya daripada harus membuat sendiri. Ada sebagian ibu-ibu yang memberikan makanan pokok pada anaknya hanya 1 kali sehari, dengan alasan anak tidak mau makan dan ibu hanya memberikan jajanan yang anak tersebut sukai. Ketertarikan anak pada makanan juga sangat rendah, balita jarang menghabiskan makanannya, dikarenakan menu yang disajikan kurang bervariasi.

Menurut Istiany dan Rusilanti (2014) salah satu faktor yang mempengaruhi status gizi adalah pola pengasuhan. Praktek pengasuhan di tingkat rumah tangga adalah memberikan perawatan (care) kepada anak dengan pemberian makanan dan kesehatan melalui sumber-sumber yang ada untuk kelangsungan hidup anak, pertumbuhan dan perkembangan. Pola asuh makan yang diterapkan kepada anak balita yang berkaitan dengan cara dan situasi makan. Jumlah dan kualitas makanan yang dibutuhkan untuk konsumsi anak penting sekali dipikirkan, direncanakan dan dilaksanakan oleh ibu ata pengasuhnya. Pola asuh makan akan selalu terkait dengan kegiatan pemberian makanan, yang akhirnya akan memberikan sumbangan status gizinya.

Terdapat balita dengan pola asuh makan yang kurang baik namun memiliki status gizi yang baik, hal ini dikarenakan pemberian susu formula yang berlebihan kepada anak serta ibu selalu menuruti makanan kesukaan balita. Sebagian balita dengan status gizi baik namun pola asuh makan yang kurang baik memiliki kebiasaan makan hanya dengan nasi dan lauk, serta sebagian balita juga menyukai mie instan, jumlah porsi makan yang disajikan juga cukup banyak. Aktivitas fisik yang dilakukan oleh balita juga kurang, anak lebih suka bermain Gudget daripada harus bermain diluar rumah. Menurut Irianto (2014), kesukaan yang berlebihan terhadap sesuatu jenis makanan tertentu atau disebut dengan 
faddismemakanan akan mengakibatkan tubuh tidak memperoleh semua zat gizi yang diperlukan.

Penelitian ini juga sejalan dengan penelitian yang dilakukan oleh Kumala, M (2013) yang meneliti tentang hubungan pola pemberian makan dengan status gizi anak usia (1-3 tahun) di posyandu Kelurahan Sidomulyo Godean Sleman dengan nilai $p$-value 0.000 . Penelitian lain juga dilakukan oleh Apriyanto, dkk (2016) yang meneliti tentang pola asuh dan status gizi balita di Kacamatan Lape, Kabupaten Sumbawa, Nusa Tenggara Barat mengatakan bahwa adanya hubungan positif dan signifikan antara perhatian terhadap ibu, pola asuh makan, dan praktik kesehatan di rumah dengan status gizi balita.

Penerapan pola asuh makan pada balita di wilayah Puskesmas Talang Bakung Kota Jambi tahun 2017 lebih dari setangah responden menerapkan pola asuh makan yang kurang baik, terdapat banyak faktor yang kemungkinan mempengaruhi penerapan pola asuh makan tersebut, salah satunya adala pengetahuan ibu yang kurang tentang gizi, sehingga petugas kesehatan terutama ahli gizi Puskesmas Talang Bakung Kota Jambi perlu memberikan edukasi kepada ibu-ibu tentang MP-ASI, dan juga memberikan informasi sumber-sumber zat gizi pada makanan, sehingga setiap keluarga khususnya pada keluarga yang berpenghasilan kurang dari UMP dapat mencukupi kebutuhan gizi dengan bahan makanan yang terjangkau.

\section{Hubungan Antara Pengetahuan Dengan Pola Asuh Makan Terhadap Status Gizi di Wilayah Kerja}

\section{Puskesmas Talang Bakung Kota Jambi Tahun 2017.}

Dari hasil penelitian didapatkan bahwa, tidak ada hubungan signifikan antara pengetahuan ibu tentang gizi yang kurang baik terhadap pola asuh makan dan status gizi balita dengan nilai $p$-value 1.000 . Ibu yang memiliki pengetahuan yang kurang baik dengan penerapan pola makan yang kurang baik, namun memiliki anak dengan status gizi baik dapat disebabkan karena pemberian makanan pokok pada anak tidak seimbang dalam segi jumlah serta komponen makanan yang disajikan tidak lengkap seperti nasi, sayur, lauk dan buah. Sebagian responden ditemukan, lebih banyak memberikan makanan pokok pada balita hanya dengan 2 jenis makanan, seperti nasi dan lauk, tanpa menggunakan sayur dan jarang makan buah. Sebagian responden juga sering memberikan mie instan dengan tambahan nasi kepada anaknya. Pemberian karbohidrat yang banyak memungkinkan anak untuk mendapatkan berat badan yang lebih, ditambah dengan aktivitas yang dilakukan oleh balita kurang.

Meurut Irianto (2014), kebutuhan nutrisi balita merupakan perioritas utama dalam mencukupi kebutuhan gizinya setiap hari. Nutrisi yang diperlukan oleh balita tentu akan sangat berperan penting dalam menunjang pertumbuhan hari demi hari. Masa balita merupakan dimana masa transisi di usia 1-2 tahun, dan untuk memenuhi nutrisi balita dimulai dengan makan makanan padat, menerima rasa serta tekstur makanan yang bari ia coba.

Angka kecukupan energi balita berasal dari rata-rata kebutuhan energi balita sehat yang tumbuh secara memuaskan. Sedangkan angka kecukupan zat-zat gizi 
didasarkan atas beberapa hasil penelitian, terutama yang dikembangkan dari kebutuhan bayi dan orang dewasa. Perbedaan kecukupan zat gizi antara kelompok balita cukup besar, sehingga Angka Kecukupan Gizi (AKG) yang dianjurkan untuk balita dibagi menjadi dua kelompok, yaitu anak usia 1-3 tahun dengan rata-rata berat badan $12,0 \mathrm{~kg}$ dan tinggi badan $90 \mathrm{~cm}$ serta anak usia 4-6 tahun dengan rata-rata berat badan $17,0 \mathrm{~kg}$ dan tinggi badan $110 \mathrm{~cm}$ (Istiany dan Rusilanti, 2013).

Untuk menjamin pertumbuhan, perkembangan dan kesehatan balita, maka perlu asupan gizi yang cukup. Menurut anjuran makanan satu hari yang dikeluarkan Departemen Kesehatan RI untuk anak usia 1-3 tahun membutuhkan 1,5 mangkok nasi (@200 gr) atau padanannya 0,5 ikan $(50 \quad$ gr $)$ atau padanannya, 2 tempe (@25 gr) atau padanannya, semangkok sayur (100 gr), seiris buah pepaya (100 gr) atau padannanya, dan segelas susu $(200 \mathrm{ml})$. Asupan gizi tersebut akan menjamin tercukupnya kebutuhan kalori untuk balita antara 1360-1830 kalori per anak per hari dan kebutuhan protein untuk balita antara 16-20 gr per anak per hari (Irianto, 2014).

Hasil penelitian juga menghasilkan bahwa, pengetahuan ibu tentang gizi yang baik terhadap pola asuh makan dan status gizi juga tidak memiliki hubungan yang signifikan dengan nilai $p$-value 0.208. ibu yang meiliki pengetahuan yang baik dengan penerapan pola asuh makan yang baik seluruhnya memiliki anak dengan status gizi yang baik pula, namun ada sebagian ibu yang memiliki pengetahuan yang baik namun penerapan pola asuh makannya kurang baik sehingga memiliki anak dengan status gizi yang kurang. Hal ini kemungkinan disebabkan beberapa faktor yang mempengaruhi, seperti ibu yang bekerja diluar rumah sehingga sedikit memiliki waktu untuk memantau tubuh kembang anaknya, ada sebagian ibu juga memiliki pendapatan keluarga dibawah UMP sehingga, keluarga tersebut kemungkinan sulit untuk menyediakan bahan pangan dikeluarganya.

Menurut Irianto (2014), ada beberapa faktor yang mempengaruhi pola pemberian makanan pendamping ASI seperti :

a. Faktor Ekonomi

Pendapatan keluarga yang memadai akan menunjang tumbuuh kembang anak karena orang tua dapat menyediakan semua kebutuhan anak baik yang primer maupun sekunder.

\section{b. Besar Keluarga}

Laju kelahiran yang tinggi berkaitan dengan kejadian kurang gizi, karena jumlah pangan yang tersedia untuk suatu keluarga yang besar mungkin cukup untuk keluarga yang besarnya setengah dari keluarga tersebut. Akan tetapi tidak cukup untuk mencegah gangguan gizi pada keluarga yang besar tersebut.

\section{c. Pembagian dalam Keluarga}

Secara tradisional, ayah mempunyai prioritas utama atas jumlah dan jenis makanan tertentu dalam keluarga. Untuk bayi dan anak-anak yang masih muda dan wanita selama tahun penyapihan, pengaruh tambahan dari pembagian pangan yang tidak merata dalam unit keluarga, dapat merupakan bencana, baik bagi kesehatan maupun kehidupan.

d. Pengetahuan 
Kurangnya pengetahuan tentang gizi atau kemampuan untuk menerapkan informasi tersebut dalam kehidupan seharihari merupakan sebab penting dari gangguan gizi (Suhardjo, 1986 dalam Irianto, 2014). Ketidak tahuan tentang cara pemberian makanan bayi dan anak balita adalah kebiasaan yang merugikan kesehatan, secara langsung dan tidak langsung menjadi penyebab utama terjadinya masalah kurang gizi pada anak, khususnya pada anak usia dibawah 2 tahun (departemen Kesehatan dan Kesejahteraan Sosial RI, 2000).

\section{KESIMPULAN DAN SARAN}

\section{Kesimpulan}

1. Status gizi kurang pada balita yang berumur 12-24 bulan di wilayah kerja Puskesmas Talang Bakung Kota Jambi tahun 2017 sebanyak 12 orang $(15,4 \%)$ dan balita dengan status gzi baik sebanyak 66 orang $(84,6 \%)$.

2. Pengetahuan ibu balita tentang gizi di wilayah kerja Puskesmas Talang Bakung Kota Jambi tahun 2017 yang kurang baik sebanyak 26 orang $(33,3 \%)$ dan yang berpengetahuan baik sebanyak 52 orang $(66,7 \%)$

3. Pola asuh makan yang diberikan pada anak balita di wilayah kerja Puskesmas Talang Bakung Kota Jambi tahun 2017 yang kurang baik sebanyak 47 orang $(60,3 \%)$, dan yang baik sebanyak 31 orang $(39,7 \%)$. Terdapat hubungan yang signifikan antara pengetahuan ibu tentang gizi dengan pola asuh makan yang diberikan kepada balita di wilayah kerja Puskesmas Talang Bakung Kota
Jambi tahun 2017 dengan nilai p-value 0.001 .

4. Terdapat hubungan yang signifikan antara pola asuh makan dan status gizi balita di wilayah kerja Puskesmas Talang Bakung Kota Jambi tahun 2017 dengan nilai $p$-value 0.022 .

5. Tidak ada hubungan yang signifikan antara pengetahuan ibu yang kurang baik dan yang baik terhadap pola asuh makan dan status gizi balita di wilayah kerja Puskesmas Talang Bakung Kota Jambi tahun 2017 dengan nilai berturutturut $p$-value 1.000 dan p-value 0.208 .

\section{Saran}

1. Diharapkan bagi Dinas Kesehatan Kota Jambi dapat memberikan masukan dan informasi dalam pertimbangan membuat perencanaan, pelaksanaan, pengembangan, dan evaluasi kesehatan masyarakat khususnya mengatasi masalah status gizi anak umur 12-24 bulan.

2. Diharapkan bagi Puskesmas Talang Bakung Kota Jambi lebih dapat memantau lagi tumbuh kembang balita, dan juga dapat memberikan penyuluhan ataupun edukasi tentang pemberian makanan tambahan pada balita yang telah berumur 6 bulan yang mencangkup jenis, jumlah serta pengolahan makanan yang tepat.

3. Untuk peneliti lain diharapkan dapat memperluas lagi variabel-variabel yang berpengaruh terhadap status gizi balita.

\section{DAFTAR PUSTAKA}


Almatsier S. 2009. Prinsip Dasar Ilmu Gizi. PT Gramedia Pustaka Utama. Jakarta

Apriyanto Denny. 2016. Pola Asuh dan Status Gizi Balita di Kacamatan Lape, Kabupaten Sumbawa, Nusa Tenggara Barat.Jurnal Gizi Pangan diakses pada tanggal 16 Desember 2016 dari www. journal.ipb.ac.id

BAPPENAS . (2010). Laporan Pencapaian Tujuan pembangunan Milenium Indonesia 2010.

BAPPENAS atau KPPN

Departemen Kesehatan RI. 2013. Laporan Hasil Riset Kesehatan Dasar Indonesia Tahun 2013. Depkes. Jakarta.

DinasKesehatan Kota Jambi, (2016). LaporanTahunan Status

GiziBadutadanBalita $d i$

SeluruhPuskesmas Kota Jambi.

Irianto, K. 2014. Gizi Seimbang dalam Kesehatan Reproduksi. Alfabeta. Bandung

Istian A dan Rusilanti. 2013. Gizi Terapan. PT Remaja Rosdakarya. Bandung.
Kumala, M. 2013. Hubungan Pola Pemberian Makan dengan Status Gizi Anak Usia Toodler (1-3 Tahun) di Posyandu Kelurahan Sidomulyo Godean Sleman. Naskah Publikasi Program Studi Ilmu Keperawatan Sekolah Tinggi Ilmu Kesehatan 'Aisyiyah Yogyakarta. Yogyakarta.

Kusumaputra RP. 2015. Hubungan Pola Asuh Dengan Pengetahuan Gizi Ibu Dengan Status Gizi dan Kesehatan Anak Balita. Skripsi Departemen Gizi Masyarakat Fakultas Ekologi Manusia Institut Pertanian Bogor. Bogor.

Notoatmodjo. 2011.

KesehatanMasyarakat. PT RinekaCipta. Jakarta.

Supariasa, dkk. 2015. Penilaian Status Gizi. Penerbit Buku Kedokteran EGC. Jakarta. 